\title{
Thermo-tolerance and heat shock protein of Escherichia coli ATCC 25922 under thermal stress using test cell method
}

\author{
Rui Li', Yage Shi' ${ }^{2}$, Bo Ling ${ }^{1}$, Teng Cheng ${ }^{1}$, Zhi Huang ${ }^{1}$, Shaojin Wang ${ }^{1,3 *}$ \\ ${ }^{1}$ College of Mechanical and Electronic Engineering, Northwest A\&F University, Yangling 712100, China, ${ }^{2}$ College of Food Science and \\ Engineering, Northwest A\&F University, Yangling 712100, China, ${ }^{3}$ Department of Biological Systems Engineering, Washington State \\ University, Pullman, WA 99164-6120, USA
}

\section{A B S T R A C T}

\begin{abstract}
Pathogenic outbreaks related to consumption of dry foods have encouraged scientific communities to study the thermal resistance of the surrogate for thermal pasteurization validation tests. The purpose of this study was to investigate thermo-tolerance relative to mRNA levels in E. coli ATCC 25922 in LB broth at three temperatures after previous heat shock, and analyze heat shock protein levels after preconditioning by using aluminum test cells. The results showed that $D$-values for $E$. coli decreased as the temperature increased from 57 to $63{ }^{\circ} \mathrm{C}$. The enhanced thermo-tolerance was found when the culture was subjected to three sub-lethal temperatures and reached maximum level at $45{ }^{\circ} \mathrm{C}$ for $5 \mathrm{~min}$. The trend of relative mRNA level and the enhanced HSP 70 protein further confirmed the increased $D$-values after heat shock treatments. After storage at cold or room temperatures for a day, however, the enhanced thermo-tolerance of E. coli ATCC 25922 could be eliminated. Longer times at a lethal temperature are needed to guarantee the required food safety in developing effective pasteurization processes.
\end{abstract}

Keywords: E. coli; Heat shock protein; Preconditioning; Thermal processing; Thermo-tolerance

\section{INTRODUCTION}

Outbreaks and recalls associated with pathogenic salmonella have been widely reported in dry foods, such as sesame seeds (Brockmann et al., 2004), spices such as paprika and pepper (Van Doren et al., 2013) and almonds (Isaacs et al., 2005). As a result, the US Department of Agriculture (USDA) regulations mandate that these agricultural products must be subjected to pasteurization processes to reduce pathogens to a reasonably acceptable level (Anon, 2007). Thermal treatments have been proposed as a promising technology for pathogen controls in postharvest agricultural products with a long and stable shelf life since they are relatively easy to apply, leave no chemical residues, and may offer some fungicidal activity (Chang et al., 2010; Liu et al., 2011).

The target pathogen cannot be directly used to conduct thermal pasteurization validation tests in food processing plants because of critical safety requirements for operators, the product and the processing environment. Using a surrogate microorganism is an alternative way for process validations, but its thermal tolerance must be known to assure it behaves similarly to the targeted pathogen. Escherichia coli ATCC 25922 is nonpathogenic and has been recommended as a surrogate species of pathogenic Salmonella for validation of thermal pasteurization (Eblen et al., 2005). It is important to determine the thermotolerance of the surrogate E. coli for developing effective thermal treatments.

The thermo-tolerance of microorganisms is influenced by several factors, such as growth phase (Martinez et al., 2003), food composition (Juneja et al., 1998; Konate et al., 2014) and preconditioning temperatures (Juneja et al., 1998; Wiegand et al., 2009). As compared to real products, a broth culture as heating medium is widely used to determine the heat resistance of pathogens (Shenoy and Murano, 1996; Juneja et al., 2001), since it provides fast and uniform

\footnotetext{
${ }^{*}$ Corresponding author:

Shaojin Wang, College of Mechanical and Electronic Engineering, Northwest A\&F University, Yangling 712100, China

Tel.: +86-29 87092391; Fax: +86- 29 87091737; E-mail: shaojinwang@nwsuaf.edu.cn
}

Received: 31 July 2016; Revised: 10 January 2017; Accepted: 11 January 2017; Published Online: 25 January 2017 
heating to achieve isothermal conditions and may represent their intrinsic heat resistance characteristics in real food (Leguerinel et al., 2007).

Thermal pasteurization protocols are developed based on the thermal resistance of pathogens under laboratory conditions. Deviation of harvest and storage conditions from room temperature prior to treatments may alter the treatment efficacy because the minimum time-temperature combinations required to reduce pathogen populations may change with pre-treatment conditions at sub-lethal warm temperatures (Juneja et al., 1998; Wiegand et al., 2009). Enhanced thermo-tolerance is related to the heat shock protein (HSP) induction (Schumann, 2003; 2007). For example, a 25 min heat shock at $46^{\circ} \mathrm{C}$ for E. coli $\mathrm{O} 157: \mathrm{H} 7$ in beef gravy results in an increase in the levels of the $69 \mathrm{kDa}$ DnaK and $60 \mathrm{kDa}$ GroEL proteins (Juneja et al., 1998), which are classified as HSP70 and HSP60, respectively (Tobian et al., 2004). When subjected E. coli to $41.5^{\circ} \mathrm{C}$ for $2 \mathrm{~h}$ heat shock, their HSP70 and HSP60 levels clearly increased (UrbanChmiel et al., 2013). After heat shock of Salmonella enteritides ATCC 4931 at $42{ }^{\circ} \mathrm{C}$ for $60 \mathrm{~min}$, seven increased proteins at different molecular weights are observed (Xavier and Ingham, 1997). The relative mRNA levels and HSP have been analyzed by real-time quantitative RT-PCR (Real-time PCR), sodium dodecyl sulphate-polyacrylamide gel electrophoresis (SDSPAGE), and Western-blot (Juneja et al., 1998; Urban-Chmiel et al., 2013). The roles of these proteins are to protect the cells against damage from high temperatures and to aid in recovery once the stress is removed (Richter et al., 2010). It is, therefore, important to determine the enhanced heat resistance of pathogens as affected by various pre-treatment conditions due to the induction and synthesis of HSP.

An aluminum test cell has been developed and applied for providing close to ideal isothermal conditions and reliable thermal death kinetic data of target pathogens (Chung et al., 2008). This test cell is designed for rapid heating of dry samples in water baths and allows easy loading and unloading of samples in a hermetically sealed cavity to evaluate the thermal resistance of vegetative cells and spores. This test cell has been successfully used to determine the $D$ - and z-values of Salmonella, E. coli K12, and Clostridium sporogenes PA 3679 spores in liquid eggs, almonds, phosphate buffer and mashed potato (Chung et al., 2008; Jin et al., 2008; Villa-Rojas et al., 2013). All of the previous research used aluminum test cells for determining the $D$ - and z-values of bacterial, but there is no report for determining the $D$-, $z$-values of bacterial and relative mRNA levels of E. coli HSP 70 expression after previous heat shock treatment by using aluminum test cells.

The objectives of this study were to (1) determine $D$ - and z-values for E. coli ATCC 25922 in broth culture at three temperatures using aluminum test cells, (2) obtain $D$-values and relative mRNA levels of E. coli HSP 70 expressions at $60{ }^{\circ} \mathrm{C}$ after heat shock at 40,45 and $50{ }^{\circ} \mathrm{C}$ for various times, (3) analyze relative mRNA levels of heat shocked E. coli at $45^{\circ} \mathrm{C}$ for $5 \mathrm{~min}$ when recovered at 4,15 and $30^{\circ} \mathrm{C}$ for various times by using real-time quantitative RT-PCR, and (4) examine the level of heat shock protein after preconditioning at $45^{\circ} \mathrm{C}$ for 5 min using SDS-PAGE and Western blot analysis.

\section{MATERIALS AND METHODS}

\section{Preparation of cell suspension}

The material was the Escherichia coli ATCC 25922 strains. It was obtained from the College of Food Science and Engineering, Northwest A\&F University (Yangling, China). Stock cultures were made in Luria-Bertani broth (LB: Beijing Land Bridge, Beijing, China) and stored at $-20{ }^{\circ} \mathrm{C}$ with $15 \%$ (vol/vol) glycerol. Stock cultures were allowed to thaw at room temperature for $5 \mathrm{~min}$. A loopful was then streaked onto LB agar and incubated at $37{ }^{\circ} \mathrm{C}$ for $24 \mathrm{~h}$. A single colony was streaked onto LB agar and incubated at $37^{\circ} \mathrm{C}$ for $24 \mathrm{~h}$. Then, a signal colony was transferred into $30 \mathrm{ml} \mathrm{LB}$ broth and incubated for $24 \mathrm{~h}$ at $37^{\circ} \mathrm{C}$. Finally, $3 \mathrm{ml}$ bacterial suspension was transferred to $300 \mathrm{ml} \mathrm{LB}$ broth and incubated again at $37^{\circ} \mathrm{C}$ for $24 \mathrm{~h}$. The cell population was adjusted to a level of $10^{\circ} \mathrm{CFU} / \mathrm{ml}$.

\section{Heating apparatus}

To investigate the thermal resistance of E. coli ATCC 25922, the aluminum test cell developed at Washington State University (Chung et al., 2008) was used. This test cell consisted of a base and a screw-up cap with O-ring between the two parts for hermetical sealing. The cavity of this test cell was $18 \mathrm{~mm}$ in diameter and $4.5 \mathrm{~mm}$ height, providing $1.28 \mathrm{ml}$ sample space. A pre-calibrated Type-T thermocouple (TMQSS-020-6, Omega Engineering Ltd., CT, USA) was installed in the center of the test cell to measure the core temperature of the sample, which was recorded every second by a data logger (CR1000, Campbell Scientific Inc., Logan, Utah, USA). The time/temperature history was measured for each run using a non-inoculated sample (LuriaBertani broth), and recorded in a computer. The recorded temperature-time history was used to determine the come-up time for each of three target temperatures. Before each use, the test cells were sanitized according to Jin et al., (2008).

\section{Effects of experimental conditions on the microbial thermo-tolerance \\ Heat treatment}

One $\mathrm{ml}$ of E. coli ATCC 25922 bacterial suspensions with $10^{9} \mathrm{CFU} / \mathrm{ml}$ cell populations was placed inside each test cell. Hermetically sealed test cells were then submerged completely in a water bath (SC-15, Scientz Biotechnology, 
Ningbo, China). The temperature of the water bath was controlled at 57,60 or $63^{\circ} \mathrm{C}$. The come-up time for the test cell core to reach within $0.5^{\circ} \mathrm{C}$ of each set-point temperature was determined and used as time zero to provide close-toideal isothermal conditions. Test cells were removed at five different time intervals, depending on the temperature, to achieve at least 5-log reductions. After holding, the test cells were immediately placed in an ice-water bath until further analysis was performed. As controls, samples in the test cells were treated in the same way for the longest holding time without heating. All the experiments were repeated three times. The semi-log plot of microbial survival curves was used to determine $D$-value (decimal reduction time) and $z$-value (temperature changes needed for $90 \%$ reduction in $D$-values).

\section{Heat shock}

One ml of E. coli ATCC 25922 bacterial suspensions was transferred to each test cell, then heat shocked at 40,45 or $50{ }^{\circ} \mathrm{C}$ temperature controlled water bath for $2,5,8$ or $11 \mathrm{~min}$, and the total test combinations were 12 treatment conditions. After heat shocking, test cells were immediately cooled in ice water. Thereafter, test cells were then submerged completely in a water bath at $60^{\circ} \mathrm{C}$. After holding for 0-5 min, duplicate test cells were removed from the water bath and immediately immersed in an ice-water bath until further analysis was performed. A sample from the test cell that was not exposed to heat shock served as an untreated control.

\section{Recovery tests}

Test cells containing $1 \mathrm{ml}$ of E. coli ATCC 25922 bacterial suspensions were sealed and then heat shocked at $45^{\circ} \mathrm{C}$ for $5 \mathrm{~min}$, and subsequently stored at 4,15 or $30^{\circ} \mathrm{C}$ for $4,8,14,24$ or $32 \mathrm{~h}$, all of these stored conditions were 15 combinations test. After each storage period, real-time PCR was conducted to detect the relative expression levels of E. coli ATCC 25922 mRNA.

\section{Microbiological enumeration}

One $\mathrm{ml}$ of E. coli ATCC 25922 bacterial suspensions was taken from test cells and then washed by using $1 \mathrm{ml}$ sterile physiologic saline. Subsequent 10 -fold serial dilutions were performed in $4.5 \mathrm{ml}$ of sterile physiologic saline; $100 \mu \mathrm{l}$ of each one was spread onto duplicated LB agar and incubated at $37^{\circ} \mathrm{C}$ for $24 \mathrm{~h}$, and cultures were counted to enumerate the plates with 30-300 colonies.

RNA isolation, reverse transcription and real-time PCR After heat shock at temperatures of 40,45 and $50{ }^{\circ} \mathrm{C}$ for various times, the total RNA from the cell suspension was extracted by using RNAiso Plus (TaKaRa, Dalian, China) following the manufacturer's instructions. The RNA concentration and purity were determined from measuring the optical density (OD) at 260 and $280 \mathrm{~nm}$ wavelengths using an Epoch microplate spectrophotometer
(BioTek Instruments. Inc., USA). The OD260/280 ratios were from 1.8 to 2.1 for all samples. A $500 \mathrm{ng}$ total RNA template was used to convert mRNA into cDNA using a Prime Script ${ }^{\mathrm{TM}}$ RT Master Mix (TaKaRa, Dalian, China) according to the manufacturer's instructions. Realtime PCR was then performed using a CFX Connect ${ }^{\mathrm{TM}}$ Real-Time PCR Detection SystemiCycler iQ5Real-time Detection System (Bio-Rad, CA, USA). For normalization, 16s-rRNA was employed. Each experiment was repeated independently at least three times, and the fold change in the expression of DnaK gene was analyzed via a $2^{-\Delta \Delta \mathrm{Ct}}$ method (Schmittgen and Livak, 2008). The primers for real-time PCR corresponding to each gene were designed using Primer 5.0 software and listed in Table 1.

In a series of recovery experiments, E. coli ATCC 25922 was heated at $45^{\circ} \mathrm{C}$ for $5 \mathrm{~min}$ and subsequently stored at 4,15 or $30^{\circ} \mathrm{C}$ for $4,8,14,24$ or $32 \mathrm{~h}$. After each storage period, Real-time PCR was conducted to detect the relative expression levels of E. coli ATCC 25922 mRNA. For protein analysis, $1 \mathrm{ml}$ aliquots from each sample were collected and centrifuged; $1 \mathrm{ml}$ aliquots from cells that had not been heat-shocked were also harvested to serve as a negative control. The cells were re-suspended in $200 \mu \mathrm{l}$ of SDS-PAGE sample buffer, boiled for $5 \mathrm{~min}$, and then carried out in a $5-10 \%$ polyacrylamide gel gradient in standard Tris/glycine chamber buffer $(0.025 \mathrm{M}$ Tris/ $\mathrm{HCl}$, $0.129 \mathrm{M}$ glycine, $0.1 \%$ SDS) at $100 \mathrm{~V}$ in a Mini-Protean II apparatus (Bio-Rad). Broad range (6.5-200 kDa; BioRad) was used as a molecular mass standard. Pictures were taken using a digital camera and the bands determined by comparison with molecular weight of the standards.

\section{Western blot analysis}

Western blotting with mouse anti-Hsp70 (LSBio) mAbs was used for identified protein fractions in cell lysates. The protein fractions obtained in electrophoresis were transferred to a $0.2 \mathrm{~mm}$ nitrocellulose membrane (Bio-Rad), described by Towbin et al., (1979). The membranes were incubated in blocking buffer with $5 \%$ non-fat milk for $1 \mathrm{~h}$ at room temperature, then washed twice in TBST buffer (TBS with $0.05 \%$ Tween $20, \mathrm{pH} 7.5)$. The membranes were then incubated at $4{ }^{\circ} \mathrm{C}$ in mouse anti-Hsp 70 overnight, washed with TBST and incubated for $60 \mathrm{~min}$ at room temperature with horseradish-peroxidase-conjugated mouseanti-IgG

Table 1: Sequences of primers for real-time PCR used in this study

\begin{tabular}{lllc}
\hline Gene & $\begin{array}{l}\text { Sense } \\
\text { antisense }\end{array}$ & Primer sequence & Size (bp) \\
\hline DnaK & $\begin{array}{l}\text { Sense } \\
\text { Antisense }\end{array}$ & TCTGGTTGGTCAGCCGGCTAA & 158 \\
16srRNA & $\begin{array}{l}\text { Cense } \\
\text { Antisense }\end{array}$ & TGCCATCGGTTATCAGCAGCAA & \\
& CATCAGGCTTGCGCCCATTGT & 173 \\
\hline \multicolumn{4}{c}{ All primers were synthesized by Invitrogen Biotech Co., Ltd. (Beijing, China) }
\end{tabular}


antibodies (Biokom). The membranes were stained using a color development kit (Bio-Rad). Analysis was conducted using Quantity One software (Bio-Rad).

\section{Statistical analysis}

$D$-values and relative mRNA level of DnaK expressions in E. coli ATCC 25922 from heat shock cells subjected to heat treatment with three independently replicated experiments were determined. Data were analyzed using the Statistical Product and Service Solutions (SPSS statistical software version 17.0). The Duncan multiple range test was used as post hoc determination of significant differences $(\mathrm{P}<0.05)$. The $Z$-values were determined from the reciprocal of the slope obtained by plotting the log of the $D$-values against exposure temperatures.

\section{RESULTS AND DISCUSSION}

\section{Heat resistance of $E$. coli at three temperatures}

A typical temperature-time history and survival curves for $E$. coli ATCC 25922 in test cell subjected to a water bath at 57, 60, and $63{ }^{\circ} \mathrm{C}$ are shown in Fig. 1. The sample core temperatures reached the set-point quickly, resulting in the similar come-up times of $20 \mathrm{~s}$ for three temperatures and providing close to ideal isothermal conditions. This come-up time was similar to that of mashed potato in a capillary tube (Chung et al., 2008), but shorter than those of mashed potato in glass tubes and of almond kernels in the same cell (Villa-Rojas et al., 2013) caused by poor heat conduction in solid materials. After short coming up times, the initial reduction of E. coli was negligible based on small intercepts of the linear regression equations. The time to reduce 4-log populations was 4.5, 2.8 and $1.5 \mathrm{~min}$ at 57,60 and $63^{\circ} \mathrm{C}$, respectively, indicating that $D$-values of E. coli ATCC 25922 decreased as the temperature increased from 57 to $63^{\circ} \mathrm{C}$, resulting in z-value of $13.3^{\circ} \mathrm{C}$. This decreasing trend of $D$-values has been observed in other studies (Rajkowski, 2012).

\section{Effect of heat shock on the heat resistance of $E$. coli}

The $D$-values and relative $m R N A$ level of DnaK expression of E.coli ATCC 25922 at $60^{\circ} \mathrm{C}$ after heat shocking at three given temperature/time combinations are listed in Table 2. The results showed that the maximum $D$-value appeared after heat shocking at $45{ }^{\circ} \mathrm{C}$ for $5 \mathrm{~min}$. The significant difference in $D$-value $(\phi<0.05)$ was observed between 40 and $45^{\circ} \mathrm{C}$ for heating $5 \mathrm{~min}$, between 45 and $50^{\circ} \mathrm{C}$ for heating 2 and $8 \mathrm{~min}$, or between $5 \mathrm{~min}$ heating and other durations at $45^{\circ} \mathrm{C}$. The enhanced thermo-tolerance was also found in E. coli O157:H7 in trypticase soy broth, L. monocytogenes Scott A in trypticase soy $+0.6 \%$ yeast extract broth and E. coli ATCC 25922 in nutrient broth after heat shock treatments (Gadzella and Ingham, 1994; Linton et al., 1992; Murano and Pierson, 1992; Yuk and Marshall, 2003). From a food safety standpoint, therefore,

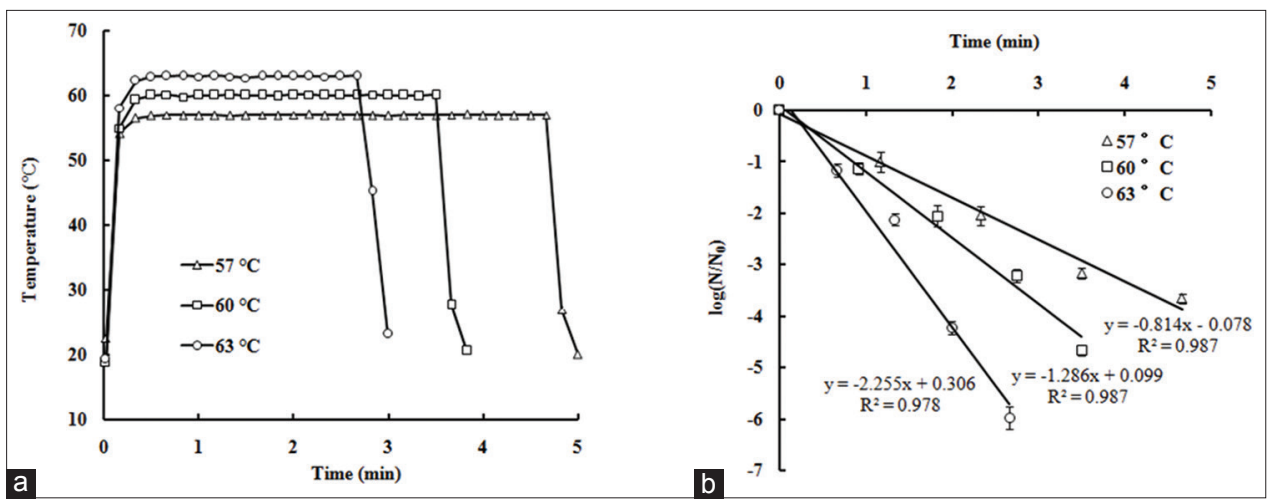

Fig 1. A typical temperature-time history (a) and survival curves (b) for E. coli ATCC 25922 in the test cell center subjected to a water bath at $\triangle 57, \square 60$, and $063^{\circ} \mathrm{C}$.

Table 2: $D$-values $(M e a n \pm S D)$ and relative mRNA level of DnaK expressions (Mean \pm SD) of Escherichia coli ATCC 25922 at $60^{\circ} \mathrm{C}$ after heat shock at three given temperatures for various times

\begin{tabular}{|c|c|c|c|c|c|c|}
\hline \multirow[t]{2}{*}{$\begin{array}{l}\text { Duration of heat shock } \\
\text { (min) }\end{array}$} & \multicolumn{3}{|c|}{$\begin{array}{c}D \text {-value (min) after following heat shock } \\
\text { temperatures }\left({ }^{\circ} \mathrm{C}\right)\end{array}$} & \multicolumn{3}{|c|}{$\begin{array}{c}\text { mRNA levels after following heat shock } \\
\text { temperatures }\left({ }^{\circ} \mathrm{C}\right)\end{array}$} \\
\hline & 40 & 45 & 50 & 40 & 45 & 50 \\
\hline $\mathrm{O}^{\#}$ & $0.78 \pm 0.01 a A^{*}$ & $0.77 \pm 0.01 a A$ & $0.79 \pm 0.01 \mathrm{aA}$ & $0.489 \pm 0.03 a A^{*}$ & $0.492 \pm 0.03 a A$ & $0.490 \pm 0.03 a A$ \\
\hline 2 & $0.91 \pm 0.02 b A$ & $0.92 \pm 0.02 \mathrm{bA}$ & $1.03 \pm 0.02 \mathrm{cB}$ & $0.581 \pm 0.03 \mathrm{bA}$ & $0.798 \pm 0.02 b B$ & $4.805 \pm 0.06 b C$ \\
\hline 5 & $0.92 \pm 0.02 b A$ & $1.25 \pm 0.03 c B$ & $1.19 \pm 0.03 \mathrm{~dB}$ & $0.795 \pm 0.02 c A$ & $16.91 \pm 0.05 \mathrm{cB}$ & $8.406 \pm 0.13 c C$ \\
\hline 8 & $1.01 \pm 0.03 \mathrm{cAB}$ & $0.96 \pm 0.02 \mathrm{bA}$ & $1.05 \pm 0.02 \mathrm{cB}$ & $1.226 \pm 0.04 \mathrm{dA}$ & $2.947 \pm 0.05 \mathrm{~dB}$ & $5.048 \pm 0.08 d C$ \\
\hline 11 & $0.95 \pm 0.04 \mathrm{bcA}$ & $0.94 \pm 0.02 \mathrm{bA}$ & $0.91 \pm 0.04 \mathrm{bA}$ & $1.048 \pm 0.02 \mathrm{eA}$ & $1.976 \pm 0.03 \mathrm{eB}$ & $0.593 \pm 0.03 e C$ \\
\hline
\end{tabular}

"0 means non-heat shock treatment and was used as a control group. *Different lower and upper case letters indicate that means are significantly different at $\mathrm{P}=0.05$ among duration of heat shock and heat shock temperatures, respectively 
heat-shocked cells need to be heated for longer time or higher temperature to achieve the same lethal level required by non-heat-shocked cells (Farber and Pagotto, 1992). The trend of relative mRNA level as a function of heat shock temperature and time was observed to be similar to that of $D$-values. The highest relative mRNA level of HSP 70 expressions of E. coli ATCC 25922 was also observed at $45^{\circ} \mathrm{C}$ for $5 \mathrm{~min}$. This indicated that after heat stress, the relative mRNA level of HSP 70 expression increased, since high temperatures might enhance the activity of transcription factors, thus strengthen the synthesis of the relative mRNA level of HSP 70 expression (Craig et al., 1991; Gabai et al., 1997).

\section{Recovery characteristics of $E$. coli after removing heat shock}

Relative mRNA levels of DnaK expression of E. coli ATCC 25922 when stored at 4,15 and $30{ }^{\circ} \mathrm{C}$ for various times after heat shocked at $45^{\circ} \mathrm{C}$ for 5 min shown in Fig. 2, which was the most heat resistant conditions. The results show that the relative mRNA level decreased after $4 \mathrm{~h}$ storage at $30^{\circ} \mathrm{C}$ but $8 \mathrm{~h}$ at $4{ }^{\circ} \mathrm{C}$ and $15^{\circ} \mathrm{C}$ and reached the level below the control after $24 \mathrm{~h}$. After storage at cold or room temperatures for a day, the enhanced thermo-tolerance of E. coli ATCC 25922 could be eliminated since the relative mRNA levels dropped down to less than that of controls. This study underlines the importance of keeping contaminated agricultural products in a room temperature condition for a period of time to avoid pretreatment conditioning. These findings are in agreement with that reported by Jørgensen et al., (1999) who indicated that heat-shock-induced thermo-tolerance of $L$. monocytogenes in tryptic phosphate broth was maintained for a longer time at 4 and $10^{\circ} \mathrm{C}$ than stored at $30^{\circ} \mathrm{C}$. However, the shorter storage duration at higher temperatures to reduce the heat shock proteins is different from that found by Juneja et al., (1998) and Auffray et al., (1995) in which E. coli $\mathrm{O} 157: \mathrm{H} 7$ cells in beef lost their thermo-tolerance after $14 \mathrm{~h}$ at $4{ }^{\circ} \mathrm{C}$ and after $24 \mathrm{~h}$ in beef at 15 or $28^{\circ} \mathrm{C}$. The persistence of heat-shock-induced thermo-tolerance may be due to different metabolic states of the tested cells (Lindquist, 1986).

\section{Levels of heat shock protein synthesis}

To determine whether the heat shock treatment used in the present study resulted in an increase in the levels of any major heat-shock protein (Hsp), the protein patterns of E. coli ATCC 25922 both in control cells and heat shocking at $45{ }^{\circ} \mathrm{C}$ for 5 min were compared following electrophoresis. Because heat-inducible members of HSP 70 family (DnaK) play an important role in thermotolerance (Schumann, 2003) meanwhile DnaK can prevent protein aggregation and promote renaturation at high temperatures (Isaacs et al., 2005). Thus in our experiment thermo-tolerance of E. coli ATCC 25922 after heat shock accompanied by the induction of HSP 70 was determined. (Fig. 3a) shows that the level of one protein with an apparent molecular mass of approximately $69 \mathrm{kDa}$ was found both in heat-shocked and control cells, but the level of $69 \mathrm{kDa}$ protein in heat-shocked cells was

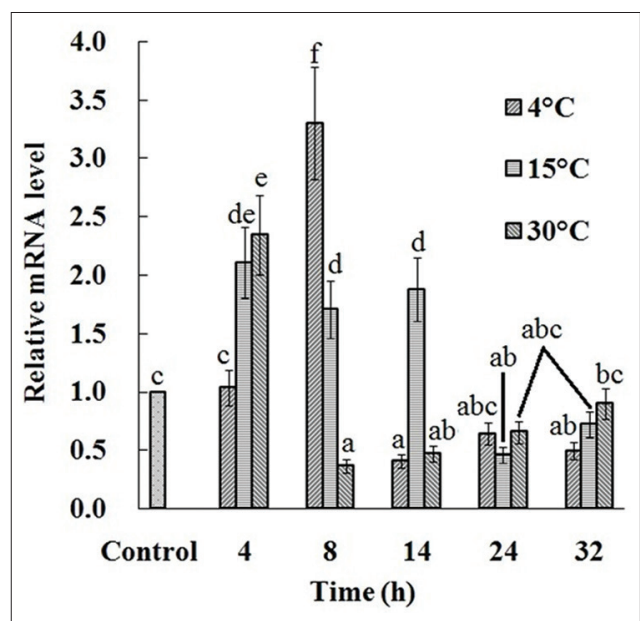

Fig 2. Relative mRNA levels of DnaK expressions of $E$. coli ATCC 25922 when stored at 4,15 and $30{ }^{\circ} \mathrm{C}$ for various times after heat shocked at $45^{\circ} \mathrm{C}$ for $5 \mathrm{~min}$. Error bars show the standard error of the means. Real-time PCR data were obtained as Ct values and amounts of DnaK mRNA were normalized to 16s-rRNA. Control means after heat shocked at $45^{\circ} \mathrm{C}$ for $5 \mathrm{~min}$. Different letters indicate that means in control are significantly different at $\mathrm{P}=0.05$ from treatments.

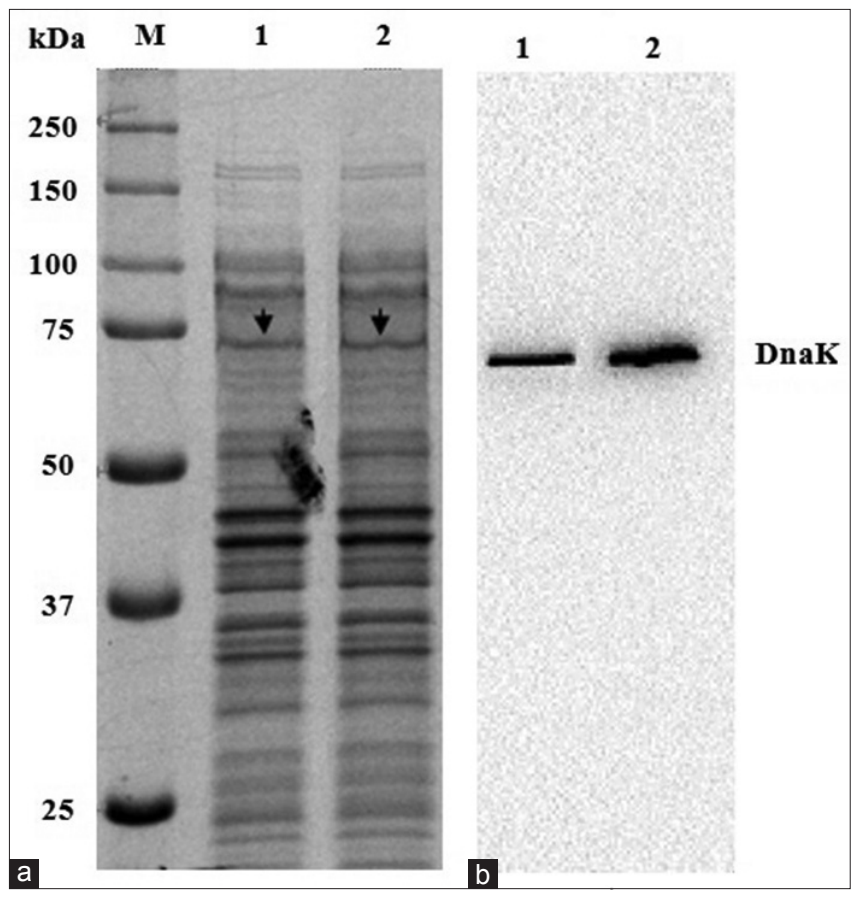

Fig 3. SDS-PAGE protein profiles of the E. coli ATCC 25922 strains (a) and Western-blot reactions of E. coli ATCC 25922 with mouse monoclonal anti-HSP70 antibodies (b). Lane 1 represents protein samples from the control, non-heat shocked cells; lane 2 represents protein samples from cells heat-shocked at $45^{\circ} \mathrm{C} .10 \mathrm{ul}$ proteins loaded in each well to determine the HSP protein. 
slightly higher than that in non-heat-shocked cells. To determine whether this protein detected by SDS-PAGE analysis corresponded to the HSP 70, a Western-blot was performed using monoclonal antibodies specific for E. coli HSP $70(69 \mathrm{kDa})$. This protein was detected on the blot in control cells, but after heat shocking at $45^{\circ} \mathrm{C}$ for $5 \mathrm{~min}$ treatment, the level of this protein increased, determined by densitometry (Fig. 3b).

The observed HSP 70 protein in controls was probably caused by many diverse heat shock proteins reported in E. coli (Neidhardt et al., 1984). However, the increased level of HSP 70 protein after heat shock was similar to results obtained by Auffray et al., (1995) and Juneja et al., (1998). This is because the loss of normal cellular functions due to sudden temperature increase is recovered by the synthesis of stress proteins such as Hsps (Juneja et al., 1998; Li and Mak, 1989; Urban-Chmiel et al., 2013).

High temperatures are stress conditions that induce responses in an organism to cope with these stresses. One of the most studied responses is the induction of heat shock proteins in pathogens. The major inducible HSP70 may reduce the inactivation level required by food safety. Determining the heat-shock response and thermo-tolerance is practically important to control E. coli ATCC 25922 in agricultural products that are heated under different harvesting, processing and storage conditions. Therefore, the enhanced heat resistance of E. coli ATCC 25922 due to heat shock must be considered while designing effective thermal processes.

\section{CONCLUSIONS}

In this study, the heat resistance of E. coli ATCC 25922 in LB broth at three temperatures was obtained with test cell methods. The preheating conditions at three sublethal temperatures resulted in increased heat resistances of $E$. coli with maximum $D$-values after heat shock at $45{ }^{\circ} \mathrm{C}$ for $5 \mathrm{~min}$. The trend of relative mRNA level after heat shock treatment was similar to that of $D$-values. The increased heat resistance could be eliminated by adding one-day storage of the contaminated products at room or cold temperatures. Avoiding heat shock proteins or increasing temperatures or treatment times must be considered to ensure food safety while designing effective thermal processes to control E. coli ATCC 25922 in postharvest agricultural products. Further experiments should be conducted to study the thermo-tolerance of E. coli ATCC 25922 in real foods and validate the results obtained in this study.

\section{ACKNOWLEDGEMENTS}

This research was conducted in the College of Mechanical and Electronic Engineering, Northwest A\&F University, and supported by research grants from General Program of National Natural Science Foundation of China (31371853). The authors thank Kexin Gao for her help on RT-PCR evaluation and Lijun An, Xiayan Liu and Yuanfeng Li for their helps on the SDS-PAGE and Western-blot analyses.

\section{Author contributions}

Conception design: S.W. Performing experiment and data analysis, drafting of the manuscript: R.L. Assist Experiment and critical revision of the manuscript: Y.S, B.L, T. C, and Z. H. All authors reviewed the manuscript.

\section{REFERENCES}

Anon. 2007. Almonds Grown in California; Outgoing Quality Control Requirements. Federal Register 72, 15021-15036. Agricultural Marketing Service, USDA.

Auffray, Y., E. Lecesne, A. Hartke and P. Boutibonnes. 1995. Basic features of the Streptococcus thermophilus heat shock response. Curr. Microbiol. 30: 87-91.

Brockmann, S. O., I. Piechotowski and P. Kimmig. 2004. Salmonella in sesame seed products. J. Food Protect. 67: 178-180.

Chang, S. S., A. R. Han, J. I. Reyes-De-Corcuera, J. R. Powers and D. H. Kang. 2010. Evaluation of steam pasteurization in controlling salmonella serotype enteritidis on raw almond surfaces. Lett. Appl. Microbiol. 50: 393-398.

Chung, H. J., S. L. Birla and J. Tang. 2008. Performance evaluation of aluminum test cell designed for determining the heat resistance of bacterial spores in foods. LWT - Food Sci. Technol. 41: 13511359.

Craig, E. and C. A. Cross. 1991. Is hsp70 the cellular thermometer. Trends Biochem. Sci. 16: 35-40.

Eblen, D. R., B. A. Annous and G. M. Sapers. 2005. Studies to select appropriate nonpathogenic surrogate Escherichia coli strains for potential use in place of Escherichia coli O157: $\mathrm{H} 7$ and Salmonella in pilot plant studies. J. Food Protect. 68: 282-291.

Farber, J. M. and F. Pagotto. 1992. The effect of acid shock on the heat resistance of Listeria monocytogenes. Lett. Appl. Microbiol. 15: 197-201.

Gabai, V. L., A. B. Meriin, D. D. Mosser, A. W. Caron, S. Rits, V. I. Shifrin and M. Y. Sherman. 1997. HSP70 prevents activation of stress kinase - A novel pathway of cellular thermotolerance. J. Biol. Chem. 272: 18033-18037.

Gadzella, T. A. and S. C. Ingham. 1994. Heat-shock, anaerobic jar incubation and fluid thioglycolate medium have contrasting effects on D-Values of Escherichia-coli. J. Food Protect. 57: 671-673.

Isaacs, S., J. Aramini, B. Ciebin, J. A. Farrar, R. Ahmed, D. Middleton, A. U. Chandran, L. J. Harris, M. Howes, E. Chan, A. S. Pichette, K. Campbell, A. Gupta, L. Y. Lior, M. Pearce, C. Clark, F. Rodgers, F. Jamieson, I. Brophy and A. Ellis. 2005. An international outbreak of salmonellosis associated with raw almonds contaminated with a rare phage type of Salmonella 
enteritidis. J. Food Protect. 68: 191-198.

Jin, T., H. Zhang, G. Boyd and J. Tang. 2008. Thermal resistance of Salmonella enteritidis and Escherichia coli K12 in liquid egg determined by thermal-death-time disks. J. Food Eng. 84: 608-614.

Jørgensen, F., T. B. Hansen and S. Knøchel. 1999. Heat shockinduced thermotolerance in Listeria monocytogenes 13-249 is dependent on growth phase, $\mathrm{pH}$ and lactic acid. Food Microbiol. 16: 185-194.

Juneja, V. K., B. S. Eblen and G. M. Ransom. 2001. Thermal inactivation of Salmonella spp. In chicken broth, beef, pork, turkey, and chicken: Determination of D- and Z-values. J. Food Sci. 66: 146-152.

Juneja, V. K., P. G. Klein and B. S. Marmer. 1998. Heat shock and thermotolerance of Escherichia coli $0157: \mathrm{H} 7$ in a model beef gravy system and ground beef. J. Appl Microbiol. 84: 677-684.

Konate, M., E. E. Akpa, L. B. Koffi, K. A. S. Kra, R. M. Megnanou and S. Niamke. 2014. Isolation of thermotolerant and high acetic acid-producing Acetobacter pasteurianus from Ivorian palm wine. Emirates J. Food Agric. 26: 773-785.

Leguerinel, I., I. Spegagne, O. Couvert, L. Coroller and P. Mafart. 2007. Quantifying the effects of heating temperature, and combined effects of heating medium $\mathrm{pH}$ and recovery medium $\mathrm{pH}$ on the heat resistance of Salmonella typhimurium. Int. J. Food Microbiol. 116: 88-95.

Li, G. C. and J. K. Mak. 1989. Re-induction of hsp70 synthesis: An assay for thermotolerance. Int. J. Hyperthermia. 5: 389-403.

Lindquist, S. 1986. The heat-shock response. Annu. Rev. Biochem. 55: 1151-1191.

Linton, R. H., J. B. Webster, M. D. Pierson, J. R. Bishop and C. R. Hackney. 1992. The effect of sublethal heat-shock and growth atmosphere on the heat-resistance of ListeriaMonocytogenes Scott-A. J. Food Protect. 55: 84-87.

Liu, Y. H., J. Tang, Z. H. Mao, J. H. Mah, S. S. Jiao and S. J. Wang. 2011. Quality and mold control of enriched white bread by combined radio frequency and hot air treatment. J. Food Eng. 104: 492-498.

Martinez, S., M. Lopez and A. Bernardo. 2003. Thermal inactivation of Enterococcus faecium: Effect of growth temperature and physiological state of microbial cells. Lett. Appl. Microbiol. 37: 475-481.

Murano, E. A. and M. D. Pierson. 1992. Effect of heat-shock and growth atmosphere on the heat-resistance of Escherichia-coli O157-H7. J. Food Protect. 55: 171-175.

Neidhardt, F. C., R. A. VanBogelen and V. Vaughn. 1984. The genetics and regulation of heat-shock proteins. Annu. Rev.
Genet. 18: 295-329.

Rajkowski, K. T. 2012. Thermal inactivation of Escherichia coli O157:H7 and Salmonella on catfish and tilapia. Food Microbial. 30: 427-431.

Richter, K., M. Haslbeck and J. Buchner. 2010. The heat shock response: Life on the verge of death. Mol. Cell. 40: 253-266.

Schmittgen, T. D. and K. J. Livak. 2008. Analyzing real-time PCR data by the comparative C-T method. Nat. Protoc. 3: 1101-1108.

Schumann, W. 2003. The bacillus subtilis heat shock stimulon. Cell Stress Chaperones. 8: 207-217.

Schumann, W. 2007. Thermosensors in eubacteria: Role and evolution. J. Biosci. 32: 549-557.

Shenoy, K. and E. A. Murano. 1996. Effect of heat shock on the thermotolerance and protein composition of Yersinia enterocolitica in brain heart infusion broth and ground pork. J. Food Protect. 59: 360-364.

Tobian, A. A. R., D. H. Canaday and C. V. Harding. 2004. Bacterial heat shock proteins enhance class II MHC antigen processing and presentation of chaperoned peptides to CD4(+) T cells. J. Immunol. 173: 5130-5137.

Towbin, H., T. Staehelin and J. Gordon. 1979. Electrophoretic transfer of proteins from polyacrylamide gels to nitrocellulose sheets: Procedure and some applications. Proc. Natl. Acad. Sci. USA. 76: 4350-4354.

Urban-Chmiel, R., M. Dec, A. Puchalski and A. Wernicki. 2013. Characterization of heat-shock proteins in Escherichia coli strains under thermal stress in vitro. J. Med. Microbiol. 62: 18971901.

Van Doren, J. M., K. P. Neil, M. Parish, L. Gieraltowski, L. H. Gould and K. L. Gombas. 2013. Foodborne illness outbreaks from microbial contaminants in spices, 1973-2010. Food Microbiol. 36: 456-464.

Villa-Rojas, R., J. Tang, S. Wang, M. Gao, D. H. Kang, J. H. Mah, P. Gray, M. E. Sosa-Morales and A. Lopez-Malo. 2013. Thermal inactivation of Salmonella enteritidis PT 30 in almond kernels as influenced by water activity. J. Food Protect. 76: 26-32.

Wiegand, K. M., S. C. Ingham and B. H. Ingham. 2009. Survival of Escherichia coli 0157:H7 in ground beef after sublethal heat shock and subsequent isothermal cooking. J. Food Protect. 72: 1727-1731.

Xavier, I. J. and S. C. Ingham. 1997. Increased D-values for Salmonella enteritidis following heat shock. J. Food Protect. 60: 181-184.

Yuk, H. G. and D. L. Marshall. 2003. Heat adaptation alters Escherichia coli 0157:H7 membrane lipid composition and verotoxin production. Appl. Environ. Microbiol. 69: 5115-5119. 